\title{
RESEARCH-IN-BRIEF
}

\section{Critical media practices}

Kritische Medienpraktiken

Sigrid Kannengießer \& Johanna E. Möller 
Sigrid Kannengießer (Prof. Dr.), Universität Bremen, Zentrum für Medien-, Kommunikations- und Informationsforschung, Linzer Str. 4, 28359 Bremen. Contact: sigrid. kannengiesser(at)uni-bremen.de. ORCID: https://orcid.org/oooo-0002-2342-9868

Johanna E. Möller (Dr.), TU Dresden, Institut für Kommunikationswissenschaft, Zellescher Weg 17, 01069 Dresden, Germany. Contact: johanna_e.moeller(at)tu-dresden.de. ORCID: https://orcid.org/oooo-0003-4377-2206 


\title{
RESEARCH-IN-BRIEF
}

\section{Critical media practices}

\section{Kritische Medienpraktiken}

\author{
Sigrid Kannengießer \& Johanna E. Möller
}

\begin{abstract}
This article develops the theoretical concept of critical media practices. Critical media practices are characterised by two aspects: 1 ) In critical media practices actors reflect on routines relating to media (as organisations, content, or technologies) and/or on the meta processes mediatisation, digitisation or datafication. 2) On the basis of this reflection actors develop alternative routines in their media practices and shape processes of mediatisation, digitisation or datafication. Critical media practices aim at influencing society and are therefore always political. Conceptualizing the term critical media practices, this article on the one hand contributes to further developing media practices as an approach in communication and media studies, on the other hand, it adds to general debates on critique in this field.
\end{abstract}

Keywords: Critical media and communication studies, datafication, data practices, media practices, political media practices.

Zusammenfassung: Dieser Artikel entwickelt das Konzept der kritischen Medienpraktiken. Kritische Medienpraktiken werden hier durch zwei Aspekte charakterisiert: 1) In kritischen Medienpraktiken reflektieren Akteur" innen Routinen, die sich auf Medien (als Organisationen, Inhalte oder Technologien) beziehen, und/oder Metaprozesse wie Mediatisierung, Digitalisierung oder Datafizierung. 2) Auf der Grundlage dieser Reflektion entwickeln Akteur*innen alternative Routinen in ihren Medienpraktiken und gestalten Prozesse der Mediatisierung, Digitalisierung oder Datafizierung. Da kritische Medienpraktiken darauf zielen, Gesellschaft und soziale Gefüge zu beeinflussen, sind sie politisch. Mit der Konzeptualisierung des Begriffs kritischer Medienpraktiken entwickelt der Artikel einerseits aktuelle Ansätze kommunikations- und medienwissenschaftlicher Medienpraxisforschung weiter, andererseits trägt er zur Diskussion über Kritik in der Medien- und Kommunikationswissenschaft im Allgemeinen bei.

Schlagwörter: Datafizierung, Datenpraktiken, kritische Kommunikations- und Medienwissenschaft, Medienpraktiken, politische Medienpraktiken.

\section{Introduction}

Critique is not only an object of media and communication studies (e.g. Lovink, 2011; Downing, 2008; Ang, 1990), e.g. critical media literacy (Kellner \& Share, 2007), critical media pedagogy (Morrell et al., 2015), critical media politics
(Dahlberg \& Phelan, 2011) equally apply a critical perspective. In the tradition of Marxist and Critical Theory, (Horkheimer \& Adorno, 2003 [1944]) Ott and Mack (2020, p. 16) in particular define critical media studies as an „umbrella term used to describe an array of theoretical perspectives that, though 
diverse, are united by their sceptical attitude, humanistic approach, political assessment, and commitment to social justice."

In conceptualising the term critical media practices, we add to this tradition, analysing and theorising how actors critically use media, thereby contributing to the research field that focuses media practices. Echoing communication and media debates on political implications of media practices (e.g. Kannengießer $\&$ Kubitschko, 2017) as well as on transformations of political agency (e.g. Milan, 2017), this article offers the concept of critical media practices in order to foster debates on media-related critical action.

Critical media practices are characterised by two aspects: 1) in critical media practices actors reflect on routines relating to media (as organisations, content or technologies) and/or on the meta processes ${ }^{1}$ mediatisation, digitisation or datafication. 2) On the basis of this reflection actors consider and develop alternatives or alternative routines, such as critical media consumption, and, in consequence, shape processes of mediatisation, digitisation or datafication. ${ }^{2} \mathrm{We}$ consider those practices as alternatives as the actors themselves perceive them as distinct to dominant practices. Therefore, we go a step further than arguing

1 A meta-process is a long-term development across regions and cultures (Krotz, 2007).

2 To define the three meta-processes: We understand mediatisation as a process which is characterised by media's increasing ubiquity and saturation into our everyday lives (Krotz, 2007). Digitisation is a process which is characterised by the increase of importance of digital media in all societal areas (Kannengießer, 2020c, 7). And datafication embraces those processes which render "into data many aspects of the world that have never been quantified before" (Cukier \& Mayer-Schoenberger, 2013, p. 29). that (media) practices are reflective (Schön, 1983) but stress that critical media practices are reflective and formative. These aspects do not necessarily occur in a linear way with reflection preceding the development of alternatives. Rather, actors can be invited or even forced to adopt alternative practices by political, social or cultural surroundings. Reflection processes can be triggered in a very practical way via transforming media practices in social or cultural contexts. The contemporary Covid pandemic, for instance, and the uses of virtual conference tools have forced reflection and discourse concerning the risks and benefits of dominant and alternative technologies.

Conceptualizing this term, we argue that political media practices are not always critical (which always implies some kind of reflection according to our definition) as media practices can shape society while the actors are using media but not reflecting the influence resulting from this use. Critical media practices, however, are always political, as critique has a practical component. We will elaborate this argument not only theoretically but also while discussing examples of critical media practices in this article.

Types of media practices and their related objectives differ. Therefore, we distinguish different modes of critical media practices. Differentiating between acting with, acting on, and opting out of media (Kannengießer \& Kubitschko, 2017; Kannengießer 2020a ; Möller \& Nowak, 2018), we will present different examples of critical media practices. Before discussing these examples, we will contextualise our definition of critical media practices by drawing on theories about and studies of the research field dealing with media practices in 
media and communication studies and combining our findings with theories about criticism. We argue that the term critical media practices helps to grasp and understand how different actors reflect on media routines and mediarelated meta processes, and which alternatives they develop.

\section{Media practice research}

For several years now, communication and media practice research has experienced a strong upswing (e.g. Burchell, et al. 2020; Stephansen \& Treré, 2020; Lünenborg \& Raetsch, 2018). Subfields traditionally focusing on individualist approaches, such as media psychology privacy research (Bräunlich et al., 2020; Trepte, 2020; adapting Marwick \& boyd, 2014), integrate practice approaches, for instance, when theorising privacy. The same applies to fields focusing on infrastructures, such as media economics (Möller et al., 2019). Beyond that, media practice theory profits from sociological and IT scholarly work as both advance research on meaning making and mundane routines from a socio-technical perspective (see for an overview Koksch et al., 2018; Wulf et al., 2018). Notions such as security or privacy are defined based on collective information practices embedded in social and cultural contexts (Dourish \& Anderson, 2006). Media practice scholars focus on what people do with media in terms of mundane action or the creation of meaningful life worlds. This implies but is explicitly not limited to the expression of content. While concepts such as 'agency' place emphasis on opinion or discourse in its manifold forms (Milan, 2017), media practice approaches embrace decisions about whether to use or not to use media (Portwood-Stacer,
2013) or digital practices such as hacking or programming (Kubitschko, 2015).

This focus on practices shows a particular potential for political communication and the media questions at stake, i.e. concerning how activists or citizens co-create the informational ecosystems they act in. Before diving deeper into this research field, we will provide a more general theoretical definition of (media) practice theory. Sociological practice theory defines practices as

"a routinized type of behaviour which consists of several elements, interconnected to one another: forms of bodily activities, forms of mental activities, 'things' and their use, a background knowledge in the form of understanding, know-how, states of emotion and motivational knowledge." (Reckwitz, 2002, pp. 249-250)

Media and communications scholars investigate such routinised behaviour in relation to media as organisations, content and technologies (Kannengießer \& Kubitschko, 2017). Couldry posed a central question to introduce the practice paradigm within communication and media studies: "What, quite simply, are people doing in relation to media across a whole range of situations and contexts?" (Couldry, 2004, p. 119). Lünenborg and Raetsch (2018, p. 14) elaborate on the particular potential this approach entails for communication and media studies: "Through practice theory, we can understand how negotiations allow different actors - let them be single actors or groups like (emerging) social movements - to participate, articulate themselves and challenge dominant viewpoints." 
The investigation of media practices offers to approach both: reproduction and change. Communication and media research has so far primarily focused on actors that aim at societal transformation, highlighting their routine activities (e.g. most recently Stephansen \& Treré, 2020; Lünenborg \& Raetsch, 2018). The particular asset of the media practice approach, that is, to show how disruption or difference is anchored in mundane repetition, comes short. Media practice research tends to overlook its potential to point to how long-term societal transformations are triggered in the everyday (Mattoni \& Treré, 2014, p. 260; Postill, 2010).

Since Couldry $(2004,2012)$ introduced the practice paradigm to communication and media studies, it has predominantly been applied by critical scholars. Mattoni (2012, p. 159), for instance, offers a helpful and detailed definition of political activists' media practices as

"(1) both routinised and creative social practices that; (2) include interactions with media objects (such as mobile phones, laptops, pieces of paper) and media subjects (such as journalists, public relations managers, other activists); (3) draw on how media objects and media subjects are perceived and how the media environment is understood and known."

The central effort of critical media practice studies is to investigate how politically engaged actors address political or societal alternatives through the uses of media (Kaun \& Velkova, 2019; Kubitschko, 2017; Kannengießer, 2016; Milan \& Hintz, 2013). Often, marginalised or single-interest actors and their empowerment via media are in the focus. Mattoni (2012), in an early study for instance, uses the practice approach to investigate media routines established by precarious workers for political protest.

The media practice approach, thus, looks back on an, admittedly short, tradition of investigating political activism in relation to media. Studies focus both on practices aimed at establishing critical or participatory positions (e.g. Stephansen, 2019; Kaun, 2015; Mattoni \& Treré, 2014;) and on media-related action as practical critique (e.g. Kubitschko, 2017; Kannengießer, 2016). So far, these studies are based on elite samples - on media routines by politically engaged actors or groups. Stephansen $(2016$, p. 37) underlines that there is a need to "conceptualize the democratic potential of citizen media practices, beyond their capacity to make previously unreported perspectives public" and to understand how citizens "contribute to the emergence of publics", while limiting the answer to how to distinguish political from other, i.e. cultural or economic, media practices. Burchell et al. (2020, p. 2778-2779) hold that the "strong program [of media practice research] goes beyond the cataloguing of practices by trying to explain the emergence, wider entanglement, or disappearance of practices." This underlines the huge potential for applying the media practice approach to understanding dynamics of societal transformation. Criticism, we argue, helps to access these dynamics in the everyday.

\section{Defining critical media practices}

As argued in the previous section, the media practice approach points to transformative, that is, political dimensions of mundane and routinised media related 
action. By distinguishing between practices of 'acting with media' and 'acting on media' (Kannengießer \& Kubitschko, 2017; Kubitschko, 2017) Kannengießer and Kubitschko carve out different types of media use. Acting with media has been the predominant paradigm in studies of digitised political activism for a long time. The verb acting is used according the meaning of the above defined practice term. Scholars look into how activists use media for political protest or the constitution of a community (Kavada, 2013; Cammaerts, 2013). Acting on media, in contrast, refers to media practices by which

"people consciously and actively seek to transform media technologies and in doing so try to change not only the devices, but also society. If we want to understand how people act in relation to media to transform society, scholars need to analyse not only how people, collectives, and organizations use media, but also how they act on media." (Kannengießer 2020a, p. 185).

Therefore, "often, although not always, acting on media is [...] an act of political participation [...] that politicises media technologies themselves." (Kannengießer 2020a, p. 178). Practices of acting on media are gaining in importance while scholars emphasise the need to maintain, manipulate or produce media infrastructures that serve their political goals. Recent studies, for instance, focus on practices of repair (Kaun \& Velkova, 2019; Kannengießer 2017), hacking (Kubitschko, 2017) or the reinvention and constant reestablishment of fragile technological infrastructures (Velkova, 2017).
As practices of acting on media directly interfere with media infrastructures and thus impact i.e. mundane communication platforms, political implications seem obvious. Yet, practices of acting with media equally point to political implications. Following the idea that informational ecosystems are enacted through repetition and routine, we assume that acting with media blends into acting on media in the long run. This theoretical assumption needs explanation. If the 'world' continues to use Facebook on a mass scale, this will cement the platform's overwhelming communicative power.

Beyond what was investigated by communication and media scholars (Kaun \& Schwarzenegger, 2014), yet overlooked by media practice research so far, is that this equally applies to the avoidance of media uses. Aside from acting with media and thereby using media as actual mediators, and acting on media, while media (as organisations, content and technologies) focussed on by media practices themselves, there is, thus, a third type of media practices which is opting out of media, meaning that actors terminate a special form of media practice (Möller \& Nowak, 2018), with potential political consequences. While media non-use has been analysed empirically (e.g. Portwood-Stacer, 2013), it has not been theorised in relation to media use.

While this points out that media practices involve political meanings, it remains unclear where this political quality ends and begins. PortwoodStacer (2013), for instance, found that opting out of the uses of Facebook can but must not express political objectives. Her investigation of active Facebook abstainers brought to the fore that while media refusal can be motivated by crit- 
ical objectives, in many cases it may represent an expression of elitism, which is connoted with class, education or taste. We differentiate between media practices along a reflexive-communicative and an action-related dimension: How can we distinguish when media are used to formulate critical positions and when not, and identify how are media used to implement the associated positions? We have argued that media practices are political. What we actually mean is that media practices either aim at structural change or result in structural change in the long run when realised on a mass scale. This, however, provides no information on whether media practices must be considered a 'political act' or not. Where do political, or critical, uses of media begin or end?

Distinguishing 'the political', 'politics' and 'critique' offers a helpful access point. Following political economist Barry (2002), we consider the analysis of any action or practice political in cases in which it relates to the political options or alternatives as offered to living in and organizing societal co-existence. The political realm of privacy, for instance, entails the various contested privacy options offered in debate or as infrastructural options (Möller \& Nowak, 2018). Whereas the political is the realm of alternatives and disagreement, 'politics' denotes practices that realise or limit these alternatives. Politics refers to "a set of technical practices, forms of knowledge and institutions" (Barry, 2002, p. 270), which are themselves the result of conflicts and agreements. While the political opens spaces for discussion and debate, politics is action. Barry mentions that politics often hinder or limit the political, i.e. by supporting one of these options and discrediting others. This can be a discursive act or acting on media, such as hacking or repairing infrastructures.

While Barry's distinction helps shed light on the complex relations between socio-political options and action that legitimates or de-legitimates any of these offers, he considers the relation between the political and politics from an economic angle. From a communication and media perspective this relation would rather be based on democratic principles such as a reflexive-discursive viewpoint towards the offered options. Criticism implies some kind of judgement (following Kant, 1997 [1790]) and norms (following Habermas, 1987 [1981]) thereby questioning dominant discourses (following Foucault, 1992 [1978]) although criticism can also develop alternatives to existing ways of thinking and practices. Vice versa, conditions or enforced practices can evoke criticism as well. Therefore, critique also has a very practical dimension (Horkheimer \& Adorno (2003 [1944]). Critical within the term critical media practices therefore means that these practices imply some kind of judgment and norms with which dominant discourses are questioned and that actors might produce alternative media (organisations, content, and technologies) with these media practices. Nicolini (2011, p. 22) argues that practices have a normative dimension as "there is a right and wrong way of doing things". Critical media practices explicitly have a normative dimension. Being reflective, normative and reconfiguring at the same time, critical media practices are political media practices as they imply the aim to shape society. Therefore, we go a step further than arguing that (media) practices are always reflective (Schön, 1983) but argue that critical media practices are reflective and formative. 
Drawing on theoretical developments from the research field dealing with media practices within the field of media and communication studies that have been explicated so far, we argue that critical media practices, can be any form of media practice which has been explained so far: they can be practices of acting with media when actors use media literally as a mediator to express the actor's criticism, they can be forms of acting on media, placing media in the focus of the practices themselves, whereby other forms of media practices are criticised and alternatives developed, or they can be a form of opting out of media, the stopping of routinised media practices - often, although not always, as a conscious criticism of media (as organizations, content, and technologies).

We finally define the term critical media practices on the basis of these explanations as follows: critical media practices either use media to express criticism (acting with media) or criticise media (organisations, content, technologies) themselves (acting on media) and/ or develop alternative media practices in different media formats (organisations, content, technologies) or quit producing or using certain media (organisations, content, technologies) by opting out of media. Having said that, we would like to come back to the two characteristics which we identify in critical media practices: 1 ) in critical media practices actors reflect on routines relating to media (as organisations, content or technologies) and/or on the meta processes mediatisation, digitisation or datafication. 2) Based on this reflection actors develop alternatives or alternative routines in their media practices and shape processes of mediatisation, digitisation or datafication. This is not necessarily a linear process. Reflec- tion must not precede the development of alternative practices. Rather, actors can be invited to or even forced to adopt alternative practices (e. g. using a particular medium, for example, using a particular messenger app to be able to stay in contact with friends and family) and resulting from that reflection processes start. For example, asking family or friends to use the mobile application Signal instead of Whatsapp to communicate and refusing the use of the latter for sharing private information or pictures, might force people to adapt alternative practices and provoke reflections on the media used and on media practices. What alternative actually means then depends on the actors: they are the ones that perceive their media practices as being alternative to those practices which they judge as being mainstream. When thus influencing society and the circumstances of social fabric, critical media practices are always political.

\section{Examples of critical media practices}

Following the differentiation between acting with, acting on, and opting out of media some examples will help illustrate the usefulness of this theoretical concept. An example for critical media practices in the dimension of acting with media is the use of media to express criticism of media technology consumption. The case of the online platform Utopia.de illustrates that media content, on the one hand, is used to criticize certain patterns of media technologies consumption while, on the other hand, also advertising the consumption of media technologies which the actors judge as being sustainable (e.g. Kannengießer, 2020a). To be more precise, in articles 
in an online magazine on the online platform Utopia.de, the socio-ecological effects of the production and disposal of digital media technologies are criticized. Moreover, media technologies which are judged as being sustainable, for example the Fairphone (see below), are advertised on the platform as is the practice of repairing (Kannengießer, 2020a). The aim of this criticism and advertising is to contribute to a sustainable society. Following our definition of critical media practices, actors in this example reflect on routines relating to media and introduce alternative routines in their media practices. The aim of this criticism and advertising is a more sustainable society, these practices can be characterised as political.

The above mentioned Fairphone and the practice of repairing media devices are examples of critical media practices on the dimension of acting on media. While repairing is not a new practice, it has gained popularity through Repair Café events, which are organised by different actors in different countries (mainly but not only North American and Western European countries), in which people meet to repair their objects of everyday life (Rosner \& Turner, 2015; Kannengießer, 2017). Media technologies are among those objects which are brought most often to these events (Kannengießer, 2017). As many people repairing media devices criticize consumption (because of the exploitation of resources and the production of waste) and try to prolong the technologies' life-span, the repairing of media practices has been defined as a consumption-critical media practice (Kannengießer, 2016, 2020a). These and similar practices were investigated by media and communication scholars such as Velkova (2017), although the 'acting on' label was not used. Velkova points to repairing softand hardware as an act of resistance vis-à-vis political infrastructures in contemporary Russia.

Also the production and use of fair media technologies is an example of critical media practices in the dimension of acting on media. The Fairphone, a smartphone, developed and produced by a Dutch company carrying the same name, is the most prominent example of fair media technologies. It is analysed from different disciplinary perspectives: in media and communication studies, the Fairphone as a technology and the company itself are analysed as media innovation (Kannengießer, 2020b) using the media practice approach (Kannengießer, 2020a). The latter reveals that the production and use of the Fairphone is some kind of consumption-critical media practice as the actors (similarly to the people repairing their media technologies) criticise the exploitation of resources needed for technology production, the production process itself, as well as the exploitation of people involved in production.

Other examples of critical media practices in the dimension of acting on media are found in data activism: "Data activism indicates social practices that take a critical approach to big data." (Milan \& Gutierrez, 2015, p. 121) It "can be seen as a form of socio-political mobilization, as it brings people (and information and technology) together for some kind of action variably contentious in nature, and explicitly addressing, confronting, or engaging with datafication" (Milan \& van der Velden, 2016, pp. 57, 62). Milan and Gutierrez (2015, p. 122; see also Milan \& van der Velden, 2016, p. 67) distinguish between "re-active" and "proactive" data activism: "Re-active data activism comprises the practices of resist- 
ance to the threats to civil and human rights that derive from corporate and government privacy intrusion. Pro-active data activism embraces those individuals and civil society organisations that take advantage of the possibility for social change and civic engagement offered by big data." Examples of re-active data activism are CryptoParties, which are (mostly public) events in which people meet to encrypt their digital media technologies and online communication processes (Kannengießer, 2019).

What these examples have in common is what we define as critical media practices in the dimension of acting on media: Following our definition of critical media practices, actors in this example reflect on routines relating to media, and present alternative routines (repairing, production/use of fair media technologies, encrypting) in their media practices. Although the aim of these practices is either a more sustainable or a safer society, these practices can be characterised as political. As media technologies themselves are in the focus of these critical media practices, these are examples for the dimension of acting on media.

Examples of critical media practices for the dimension of opting out of media, are found in studies such as the above mentioned analysis of reasons why people quit the use of Facebook (PortwoodStacer, 2013). This study shows that rejecting the uses of media can be (yet often is not) motivated by criticism of the company and the pattern of media use. Following our definition of critical media practices, actors opting out of media also reflect on routines relating to media, while the alternative routine here is the rejection of media use. Also, opting out of media has political implications as it may aim to call into question the status of media as communicative conditio sine qua non.

\section{Conclusion}

In this article, we conceptualise the term critical media practices regarding those practices in which 1) actors reflect on routines relating to media (as organisations, content or technologies) and/or on the meta processes mediatisation, digitisation or datafication, and 2) on the basis of this reflection actors develop alternative routines in their media practices and thereby shape processes of mediatisation, digitisation or datafication. These aspects do not occur in a linear way, meaning that the reflection does not necessarily precede the development of alternative practices. What alternative actually means depends on the actors: they are the ones that perceive their media practices as being alternative to those practices which they then judge as being mainstream.

As they aim at influencing society and the circumstances of social fabric, critical media practices, we argue are always political.

To understand political engagement using media requires embracing iterative processes between routine and change, between actors and media infrastructures. Much of what this insight contains has already been debated by communication scholars who focused on media practices or political agency. Media practice scholars have provided valuable insights into the political implications of routine mundane media-related action. Yet, what needs to be added to media practice research is differentiation between political media practices which influence society but not necessarily in an intentional or conscious way and those media practices which critically reflect on routines 
relating to media, and at the same time develop alternative routines in the use of media. The concept of critical media practices embraces these practices. Using the differentiation of acting with, acting on, and opting out of media which was developed in the field of media practices, we argue that critical media practices can occur in all of these dimensions. Reflection on routinised uses of media (technologies) and meta processes such as datafication are a cross-cutting aspect in all of these dimensions.

The concept of critical media practices underlines the iterative relation between actors and informational ecosystems beyond discursive action. At the same time it integrates reflection and selfidentification in relation to informational ecosystems. The notion of critical media practices helps to understand political engagement in relation to media by including all media-related activities based on reflections on the relation of individuals or collectives and society. Developing the term critical media practices, this article contributes to the research field of media practices while simultaneously adding to discussions about critique in media and communication studies in general, which was sketched out at the very beginning of this text. Thereby, it also follows an understanding of the term criticism as implying some kind of judgement (Kant, 1997 [1790]) and norms (Habermas, 1987 [1981]), thereby involving a questioning of dominant discourses (Foucault, 1992 [1978]) as well as having a practical dimension (Horkheimer \& Adorno (2003 [1944]).

Using this understanding of critique, media and communication, scholars are able to analyse the way different actors critically reflect on and use media (technologies), while, at the same time, apply- ing a critical perspective to these media practices.

\section{References}

Ang, I. (1990). Culture and communication: Towards an ethnographic critique of media consumption in the transnational media system. European Journal of Communication, 5(2), 239-260. https://doi. org/10.1177/0267323190005002006

Barry, A. (2002). The anti-political economy. Economy and Society, 31(2), 268-284. https://doi.org/10.1080/030 85140220123162

Bräunlich, K., Dienlin, T., Eichenhofer, J., Helm, P., Trepte, S., Grimm, R., Seubert, S., \& Gusy, C. (2020). Linking loose ends: An interdisciplinary privacy and communication model. New Media \& Society. Advance online publication. https://doi.org/10.1177/ 1461444820905045

Burchell, K., Driessens, O. \& Mattoni, A. (2020). Practicing media - mediating practice: Introduction. International Journal of Communication, 14, 2775-2778. https:// ijoc.org/index.php/ijoc/article/view/11202

Cammaerts, B. (2015). Social media and activism. In R. Mansell \& P. Hwa (Eds.) The International Encyclopedia of Digital Communication and Society (pp. 10271034). Wiley-Blackwell.

Couldry, N. (2004): Theorising media as practice. Social Semiotics, 14(2), 115-132. https://doi.org/10.1080/1035033042 000238295

Couldry, N. (2012): Media, society, world: social theory and digital media practice. Polity.

Cukier, K., \& Mayer-Schoenberger, V. (2013). The rise of big data: How it's changing the way we think about the world. Foreign Affairs, 92(3), 28-40. https://doi. org/10.2469/dig.v43.n4.65

Dahlberg, L., \& Phelan, S. (Eds.). (2011). Discourse theory and critical media politics. Palgrave McMillan London. 
Dourish, P., \& Anderson, K. (2006). Collective information practice: Exploring privacy and security as social and cultural phenomena. Human-Computer Interaction, 21(3), 319-342. https://doi. org/10.1207/s15327051hci2103_2

Downing, J. (2008). Social movement theories and alternative media: An evaluation and critique. Communication, Culture and Critique, 1(1), 40-50. https://doi. org/10.1111/j.1753-9137.2007.00005.x

Foucault, M. (1992 [1978]). Was ist Kritik? [What is critique?]. Merve Verlag.

Habermas, J. (1987 [1981]). Theorie des kommunikativen Handelns[Theory of communicative action] (4th ed.). Suhrkamp.

Horkheimer, M., \& Adorno, T. (2003 [1944]). Dialektik der Aufklärung. Philosophische Fragmente [Dialectic of enlightenment. Philosophical fragments]. Fischer.

Kannengießer, S. (2016). Conceptualizing consumption-critical media practices as political participation. In L. Kramp, N. Carpentier, A. Hepp, R. Kilborn, R. Kunelius, H. Nieminen, T. Olsson, S. Tosoni, I. Tomanic Trivundža, \& Pille PruulmannVengerfeldt (Eds.), Politics, civil society and participation (pp. 193-207). Tartu University Press.

Kannengießer, S. (2017). 'I am not a consumer person' - Political participation in Repair Cafés. In J. Wimmer, C. Wallner, R. Winter, \& K. Oelsner (Eds.), (Mis)Understanding political participation. Digital practices, new forms of participation and the renewal of democracy (pp. 78-94). Routledge.

Kannengießer, S. (2019): Reflecting and acting on datafication. CryptoParties as an example of critical media practices. Convergence: The International Journal of Research into New Media Technologies, 26(5-6), https://doi.org/10.1177/13548 56519893357

Kannengießer, S. (2020a). Consumption-critical media practices: acting on media for sustainability. In H. Stephansen \& E. Treré (Eds.), The turn to practice in media research: implications for the study of citizen- and social movement media (pp. 176-188). Routledge.

Kannengießer, S. (2020b). Fair media technologies: innovative media devices for social change. The Journal of Media Innovations, 6(1), 38-49. https://doi. org/10.5617/jomi.7832

Kannengießer, S. (2020c). Nachhaltigkeit und das „gute Leben“ - Zur Verantwortung der Kommunikations- und Medienwissenschaft in digitalen Gesellschaften [Sustainability and the "good life“ - Responsabilities of communication and media research in digital societies]. Publizistik 65(1), 7-20. https://doi.org/10.1007/ s11616-019-00536-9

Kannengießer, S., \& Kubitschko, S. (2017). Editorial. Acting on media: influencing, shaping and (re)configuring the fabric of everyday life. Media and Communication, 5(3), 1-4. https://doi.org/10.17645/mac. v5i3.1165

Kant, I. (1996 [1790]). Kritik der Urteilskraft [Critique of judgement] (ed. by Otfried Höffe, 14th ed.). Suhrkamp.

Kaun, A. (2015). “This space belongs to us!”. Protest spaces in times of accelerating capitalism. In L. Dencik \& O. Leistert (Eds.), Critical Approaches to social media protest. Contentions and debates (pp. 91-110). Rowman \& Littlefield Publishers.

Kaun, A., \& Schwarzenegger, C. (2014). No media, less life? Online disconnection in mediatized worlds. First Monday, 19(11), without page numbers https://doi. org/10.5210/fm.v19i11.5497

Kaun, A., \& Velkova, J. (2019). Algorithmic resistance: media practices and the politics of repair. Information, Communication \& Society, 24(4) https://doi.org/10.1080/13 69118X.2019.1657162

Kavada A. (2013): Internet cultures and protest movements: the cultural links between strategy, organizing and online communication. In B. Cammaerts, A. Mattoni, \& P. 
McCurdy (Eds.), Mediation and protest movements (pp. 75-94). Intellect.

Kellner, D., \& Share, J. (2007). Critical media literacy: Crucial policy choices for a twenty-first-century democracy. Policy Futures in Education, 5(1), 59-69. https:// doi.org/10.2304/pfie.2007.5.1.59

Kocksch, L., Korn, M., Poller, A., \& Wagenknecht, S. (2018). Caring for IT security: Accountabilities, moralities, and oscillations in IT security practices. Proceedings of the ACM on Human-Computer Interaction, 2(CSCW), 1-20. https://doi. org/10.1145/3274361

Krotz, F. (2007). The meta-process of mediatization as a conceptual frame. Global Media and Communication, 3(3), 256260. https://doi.org/10.1177/1742766507 0030030103

Kubitschko, S. (2015). Hackers' media practices: Demonstrating and articulating expertise as interlocking arrangements. Convergence - The international journal for research into new media technologies, 21(3), 388-402. https://doi.org/10.1177/ 1354856515579847

Kubitschko, S. (2017). Acting on media technologies and infrastructures: Expanding the media as practice approach. Media, Culture \& Society, 40(4), https://doi. org/10.1177/0163443717706068

Lovink, G. (2011). Networks without a cause. A critique of social media. Polity.

Lünenborg, M., \& Raetzsch, C. (2018). From public sphere to performative publics: Developing media practice as an analytic model. In S. Foellmer, M. Lünenborg, \& C. Raetzsch (Eds.), Media practices, social movements, and performativity. Transdisciplinary approaches (pp. 13-35). Routledge.

Marwick, A. E., \& d. boyd (2014). Networked privacy: How teenagers negotiate context in social media. New Media \& Society, 16(7), 1051-1067. https://doi.org/10.1177/ 1461444814543995
Mattoni, A. (2012). Media practices and protest politics. How precarious workers Mobilise. Ashgate.

Mattoni, A., \& Treré, E. (2014). Media practices, mediation processes, and mediatization in the study of social movements. Communication Theory, 34(3), 252-271. https://doi.org/10.1111/comt.12038

Milan, S. (2017). Political agency, digital traces, and bottom-up data practices. International Journal of Communication, 12, 507-527. https://ijoc.org/index.php/ijoc/ article/view/6709/2251

Milan, S., \& Hintz, A. (2013). Networked collective action and the institutionalized policy debate: Bringing cyberactivism to the policy arena? Policy \& Internet, 5(1), 7-26. https://doi.org/10.1002/poi3.20

Milan, S., \& Gutierrez, M. (2015). Citizens' media meets big data: The emergence of data activism. Mediaciones, 14, 120-133. https://doi.org/10.26620/uniminuto.mediaciones.11.14.2015.120-133

Milan, S., \& van der Velden, L. (2016). The alternative epistemologies of data activism. Digital Culture \& Society, 2(2), 57-74. https://doi.org/10.1177/1527476 419837739

Möller J. E., Nölleke-Przybylski, P., Voci, D., von Rimscha, M. B., Altmeppen, K. D., \& Karmasin, M. (2019). A motivation-based typology of media companies' cross-border engagement. European Journal of Communication, 34(3), 300-318. https://doi. org/10.1177/0267323119844416

Möller, J. E., \& Nowak, J. (2018). Don’t hate the media - act on media. Civil society agents' media-oriented practices on encryption/privacy. Presentation on the ECREA conference in Lugano, 31 October -8 November 2018.

Morrell, E., Lopez, J., \& Duenas, R (2015). Critical media pedagogy. Teachers College Press.

Nicolini, D. (2017). Practice theory as a package of theory, method and vocabulary: affordances and limitations. In M. Jonas, 
B. Littig, \& A. Wroblewski (Eds.), Methodological reflections on practice oriented theory (pp. 19-34). Springer.

Ott, B. L., \& Mack, R. L. (2020). Critical media studies. An introduction (3rd. ed). Wiley Blackwell.

Portwood-Stacer, L. (2013). Media refusal and conspicuous non-consumption: The performative and political dimensions of Facebook abstention. New Media \& Society, 15(7), 1041-1057. https://doi. org/10.1177/1461444812465139

Postill, J. (2014). Democracy in an age of viral reality. A media epidemiography of Spain's indignados movement. Ethnography, 15(1), 51-69. https://doi.org/10.1177/1466 138113502513.

Reckwitz, A. (2002). Toward a theory of social practices: a development in culturalist theorizing. European Journal of Social Theory, 5(2), 243-263. https://doi. org/10.1177/13684310222225432

Rosner, D., \& Turner, F. (2015). Theaters of alternative industry: Hobbyist repair collectives and the legacy of the 1960s American counterculture. In H. Plattner, C. Meinel, \& L. Leifer (Eds.), Design thinking research (pp. 59-69). Springer International Publishing.

Schön, D. A. (1983). The reflective practitioner. How professionals think in action. Basic Books.

Stephansen, H. (2016). Understanding citizen media as practice: agents, processes, publics. In M. Baker \& B. Blaagaard (Eds.), Citizen media and public spaces: diverse expressions of citizenship and dissent (pp. 25-41). Routledge.

Stephansen, H. (2019). Conceptualizing a distributed, multi-scalar global public sphere through activist communication practices in the World Social Forum. Global Media and Communication. 15(3), 345-360. https:// doi.org/10.1177/1742766519872777

Stephansen, H., \& Treré, E. (Eds.). (2019). Citizen media and practice: Currents, connections, challenges. Routledge.
Trepte, S. (2020). The social media privacy model: Privacy and communication in the light of social media affordances. Communication Theory. Advance online publication. https://doi.org/10.1093/ct/qtz035

Velokova, J. (2018). Repairing and developing software infrastructures: The case of Morevna Project in Russia. New Media \& Society 20(6), 1-17. https://doi. org/10.1177/1461444817731922

Wulf, V., Pipek, V., Randall, D., Rohde, M., Schmidt, K., \& Stevens, G. (2018). Socioinformatics - A practice-based perspective on the design and use of IT artefacts. Oxford University Press. 